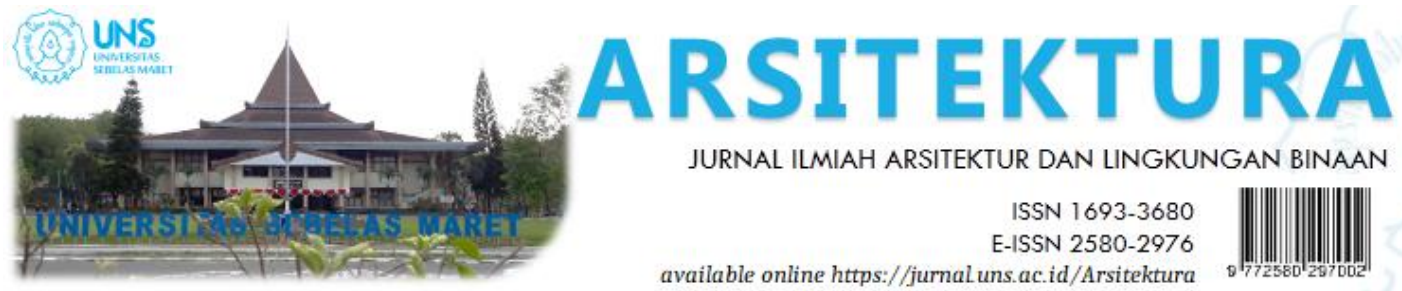

Volume 18 Issue 1 April 2020, pages:63-73

\title{
Peningkatan Kenyamanan Termal dan Pencahayaan Alam Gedung Sekolah Dasar di Kawasan Padat Hunian di Surabaya
}

\section{Thermal and Daylighting Design Improvement of an Elementary School Building In Densely Populated Area In Surabaya}

\author{
Sri Nastiti N. Ekasiwi ${ }^{1 *}$, I Gusti Ngurah Antaryama ${ }^{2}$, Erwin Sudarma ${ }^{3}$, Ima Defiana ${ }^{4}$, \\ Asri Dinapradipta ${ }^{5}$, FX Teddy Badai Samodra ${ }^{6}$, Bambang Soemardiono $^{7}$, Irvansyah ${ }^{8}$, \\ Angger Sukma ${ }^{9}$, Colinthia Erwindi ${ }^{10}$ \\ Departemen Arsitektur, FADP Institut Teknologi Sepuluh Nopember ${ }^{1 *}$ \\ Email: nastiti@arch.its.ac.id \\ Departmen Arsitektur, FADP Institut Teknologi Sepuluh Nopember ${ }^{2,3,4,5,6,7,8,9,10}$
}

DOI: https://doi.org/10.20961/arst.v18i1.36146

Received: November 29, 2019 Revised : March 23,2020 Accepted: March 23,2020 Available online: April 30, 2020

\begin{abstract}
A humid tropical climate characterized by high temperatures, relative humidity and solar radiation results in uncomfortable environmental conditions. Discomfort will be worse if the building is in a dense urban area. Densely building masses often weaken the local wind speed which is necessary for evaporative cooling process in tropical climate. In addition, the narrow distance between buildings can reduce access to daylight. Both of these environmental problems were experienced by SDIT Al Uswah Surabaya, which building is located in a densely populated neighbourhood. Along with the development program of educational facilities and infrastructure at the school, improving environmental conditions with passive concept is maintained and prioritized. Embodiment of the environment with the Selective Environment approach is used in this activity. The results of this activity will be in the form of design proposals for improving ventilation and lighting in classrooms. The limitation of expanding openings becomes an obstacle in fulfilling the natural ventilation and lighting requirements. In addition, the design of a three-storey building with a single loaded corridor requires special consideration for the design of sun shading that is safe for elementary school-age children, but still supports passive lighting and ventilation.
\end{abstract}

Keywords: thermal environment; daylighting environment; elementary school; comfort and healthy environment; dense urban area; Kampung Kejawan Surabaya

\section{PENDAHULUAN}

Desain arsitektur sangat erat hubungannya dengan iklim dan kenyamanan pengguna. Ketiga hal tersebut digambarkan sebagai Vitruvian Tripartide Model of Environment oleh Hawkes et.al, (2001). Arsitektur mempunyai peran dalam desain lingkungan, dimana bentuk dan bahan bangunan bertindak sebagai perantara antara lingkungan alam yang terbentuk (iklim), dan kondisi lingkungan yang didalamnya harus menciptakan lingkungan yang nyaman (comfort). Terkait dengan hal tersebut, arsitektur dipengaruhi oleh iklim setempat. 
Pada iklim tropis yang ditandai dengan kondisi rata-rata yang panas dan lembab, seperti di Surabaya, pencapaian kondisi kenyamanan termal sulit dicapai. Kondisi padat dengan jarak antar bangunan yang sempit di lokasi padat hunian memperparah kondisi tersebut. Keterlibatan pemilihan orientasi yang tepat, elemen bangunan yang dirancang untuk merespon kondisi iklim tropis, dalam hal ini bukaan lebar untuk memperoleh aliran angin dan cahaya untuk penerangan ruang sulit mengakomodasi tersedianya kenyamanan ruangan.

Sekolah Dasar Islam Terpadu (SDIT) Al Uswah berada di lokasi padat hunian Jalan Kejawan Gebang Sukolilo Surabaya (gambar 1). Kampung tersebut masih didominasi oleh bangunan rumah tinggal dan tempat usaha, dengan tinggi satu sampai dua lantai. Permasalahan yang dihadapi adalah pertetanggaan bangunan yang sangat rapat, ataupun berbatasan dengan halaman warga, sehingga untuk memenuhi kebutuhan pengembangan fasilitas sekolah pun, pengembangan dilakukan vertikal. SDIT Al Uswah melakukan peningkatan fasilitas ruang kelas dengan membangun bangunan kelas tiga lantai. Dengan posisi bangunan lebih tinggi dari bangunan sekitarnya dapat dipandang positif maupun negatif dari sisi pandang penyelesaian lingkungan termal, yakni dari sisi positif kondisi tersebut akan mendapatkan aliran angin yang lebih banyak, atau dari sisi negatif, akan mendapat paparan sinar matahari yang lebih banyak juga. Pengalaman paska huni yang sudah lebih dari sepuluh tahun, keluhan terjadi bahwa kondisi kelas kurang nyaman, baik dari segi penghawaan maupun pencahayaan.

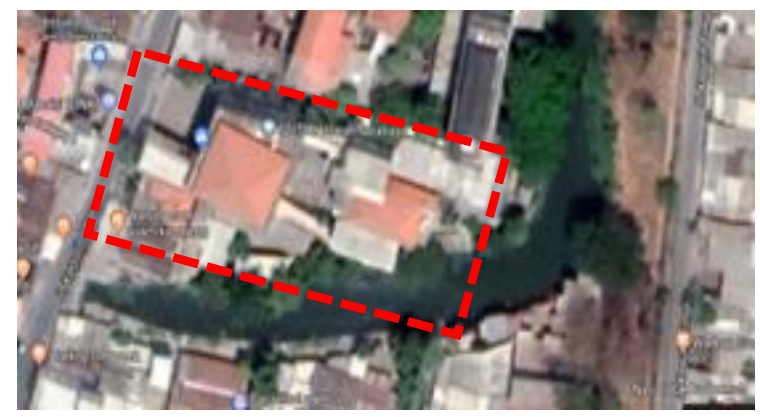

Gambar 1. Posisi Gedung SDIT Al Uswah dikelilingi bangunan lain yang sangat rapat.
Penelitian terdahulu terhadap sekolah-sekolah dasar dilakukan dan menyatakan bahwa desain kelas mempunyai dampak pada progres belajar siswa (Barret, P, et.al, 2015; Marchand, et.al. 2014). Hasil penelitiannya menegaskan bahwa lingkungan alam (naturalness) yang meliputi: cahaya, kesegaran udara, suara dan warna mempunyai dampak yang kuat terhadap keberhasilan siswa dalam belajar. Penelitian sebelumnya melaporkan bahwa hasil tes bahasa meningkat jika temperatur ruangan dikurangi (Wargocki, P, et.al 2007 dalam Barret, et.al 2015). Dengan kata lain, jika ruangan semakin sejuk, keberhasilan siswa dalam mengerjakan tes bahasa akan lebih baik.

Standar kenyamanan lingkungan dikemukakan oleh beberapa ahli dari hasil studinya. Ada juga yang sudah dibakukan menjadi acuan dalam penelitian. ASHRAE 55 (2004) standar kenyamanan dengan memperhatikan adaptasi penghuni terhadap kondisi termal bangunan, sehingga menghasilkan toleransi terhadap kondisi termal lebih tinggi. Standar yang dikeluarkan ASHRAE diakui secara internasional. Dalam lingkup iklim tropis beberapa peneliti menghasilkan rentang kenyamanan termal (Wong dan Khoo 2005). Studinya tentang kenyamanan termal pada ruang kelas berpenghawaan alami di Singapura. menghasilkan rentang antara $27,0-29,3^{\circ} \mathrm{C}$ merupakan nilai yang dapat diterima sebagai rentang suhu comfort, yang nilainya lebih tinggi dari standar ASHRAE 55. Sedangkan SNI63902011 membakukan bahwa suhu nyaman terletak dalam rentang $25,5 \pm 1,5^{\circ} \mathrm{C}$ RH $60 \pm 5 \%$.

Standar kondisi lingkungan di bangunan sekolah ditentukan berdasarkan kebutuhan pada aktifitas di sekolah. Untuk standar kecepatan angin tidak tersedia standar yang pasti, sehingga disesuaikan dengan kebutuhan pada tiap ruang. Standar kondisi lingkungan yang mencakupi kenyamanan termal, pencahayaan dan akustik dijelaskan pada Tabel 1. 
Tabel 1. Standar kenyamanan dalam berbagai kondisi lingkungan

\begin{tabular}{llll}
\hline No & $\begin{array}{l}\text { Kondisi } \\
\text { Lingkungan }\end{array}$ & $\begin{array}{l}\text { Standar } \\
\text { Kenyamanan }\end{array}$ & Sumber \\
\hline 1. & $\begin{array}{l}\text { Suhu } \\
\text { Temperatur }\end{array}$ & $18-28^{\circ} \mathrm{C}$ & $\begin{array}{l}\text { KEPMENKES } \\
\text { No 1405, 2002 }\end{array}$ \\
\hline 2. & Kelembaban & $40-60 \%$ & $\begin{array}{l}\text { KEPMENKES } \\
\text { No 1405, 2002 }\end{array}$ \\
\hline 3. & $\begin{array}{l}\text { Kecepatan } \\
\text { Angin }\end{array}$ & $\begin{array}{l}\text { Sesuai } \\
\text { Kebutuhan }\end{array}$ & - \\
\hline 4. & Pencahayaan & 200-300 Lux & $\begin{array}{l}\text { KEPMENKES } \\
\text { No. 1429, 2006 }\end{array}$ \\
\hline 5. & Kebisingan & $35-45 \mathrm{~dB}$ & $\begin{array}{l}\text { KEPMENKES } \\
\text { No. 1429, 2006 }\end{array}$ \\
\hline
\end{tabular}

Sumber: KEPMENKES No 1405 (2002), KEPMENKES No. 1429 (2006)

Kecepatan angin tidak mempunyai standar tertentu dalam menentukan kenyamanan. Ada tiga unsur yang paling menentukan kenyamanan termal. Unsur tersebut adalah temperatur, kelembapan relatif dan kecepatan angin. Nilai kecepatan angin yang dibutuhkan untuk mencapai kenyamanan termal akan berubah sesuai kondisi temperatur dan kelembapan ruangan.

Berikut formula untuk menghitung kecepatan angin menurut Aynsley (1977):

\section{$W S=0,15(D B T-27,2)+0,56(R H-60) 10 \mathrm{~m} / d t$}

Adapun aspek desain arsitektural yang mempengaruhi kondisi termal dalam bangunan adalah:

Bentuk bangunan: dinyatakan dalam perbandingan antara total luas permukaan terhadap keseluruhan volumenya (surface to volume ratio) Hal lain yang bisa mengindikasikan bentuk adalah perbandingan antara panjang banding lebar bangunan (aspect ratio). Strategi rancang bangunan dengan sistem penghawaan alami mendorong terjadinya pergerakan angin dan meminimalisir penerimaan panas (Szokolay S. V., 2004). Konsekuensinya bangunan memanjang dengan kedalaman ruang tunggal. Selubung bangunan memiliki area bukaan yang cukup luas untuk mengalirkan angin.

Orientasi Bangunan: Orientasi terhadap matahari diwakili dengan arah mata angin. Arah hadap bangunan berakibat pada jumlah perolehan panas yang diakibatkan oleh intensitas panas yang berbeda-beda di orientasi yang berbeda.

Material bangunan: semua properti bahan bangunan mempengaruhi daya hantar panas Bukaan bangunan beserta kelengkapannya: Lazim disebut fenestration, dengan ukuran jendela, posisi, jenis kaca, serta peneduh atau pembayang matahari. Selain berpengaruh pada panas bangunan, bukaan bangunan mempengaruhi efektifitas ventilasi, yang dapat membantu penghapusan panas ruangan.

Konfigurasi ruang luar: Ruang luar yang padat adakalanya berfungsi untuk menghalangi panas, sehingga menguntungkan dari segi perolehan panas. Namun dari segi penghawaan, belum tentu.

Sedang aspek desain yang mempengaruhi terang ruangan adalah:

Bukaan yakni luas dan posisi serta elemenelemen bukaan yang mempengaruhi perolehan cahaya; kedalaman ruang; penghalang di luar (bangunan lain, pagar, pepohonan); warnawarna permukaan di dalam ruangan maupun di luar ruangan; orientasi bukaan.

Tulisan ini melaporkan kegiatan pengabdian pada masyarakat (PPM) yang bertujuan untuk memberikan alternatif arahan desain penghawaan dan pencahayaan pada ruang ruang kelas SDIT Al Uswah Surabaya dalam rangka untuk peningkatan kualitas kenyamanan termal dan visual dalam ruang kelas. Sedang manfaat dari kegiatan ini adalah terutama untuk meningkatkan motivasi belajar siswa dimana akhirnya dapat meningkatkan prestasi belajar mereka.

\section{METODE}

Luaran yang berupa usulan desain dari kegiatan ini melibatkan peran serta berbagai pihak yang berkepentingan yakni pengelola: Yayasan Ukuwah Islamiah dan pengguna: Guru-guru SDIT Al Uswah. Hal ini diharapkan agar desain benar-benar ramah pengguna (respect to users). Untuk itu strategi yang diterapkan adalah: case based design dan community based design. Case based Design (desain berbasis kasus) kasus didalami dari data fisik dan pengukuran penghawaan dan pencahayaan. Community based design (desain berbasis Komunitas) 
komunitas yang terdiri dari pengelola Yayasan sebagai penyandang dana dan guru-guru serta siswa dilibatkan dalam penjaringan masalah yang dihadapi serta masukan yang terkait.

Dalam aplikasi usulan rancangan menggunakan pendekatan selektif environment yakni pendekatan rancangan berbasis strategi pasif. Strategi pasif adalah strategi yang mendayagunakan lingkungan untuk mencapai kenyamanan guna penghematan energi (Hawkes D., et al, 2002).

Seluruh rangkaian kegiatan PPM ini akan dilaksanakan dalam enam (6) bulan. Adapun jenis kegiatan dijabarkan sebagai berikut:

1. Melakukan survai lapangan dengan mengambil data fisik komponen ruang, bangunan dan lingkungan dalam batasan Kampung Kejawan Gebang, diikuti pengukuran termal dan pencahayaan pada ruang-ruang kelas untuk mengidentifikasi masalah

2. Melakukan analisis dan sintesis terhadap masalah yang telah diidentifikasi, yang diujudkan dalam bentuk kriteria dan konsep desain.

3. Membuat usulan desain

4. Melakukan pemaparan dan diskusi di dua tahap yang berbeda, yakni setelah menyusun kriteria dan konsep, dilanjutkan setelah tersusunnya usulan desain.

5. Desiminasi hasil.

Lokasi PKM berada kota Surabaya yang secara astronomis terletak diantara $07^{\circ} 9^{\prime}-7^{\circ} 21^{\prime}$ Lintang Selatan dan $112^{\circ} 36^{\prime}$ - $112^{\circ} 54^{\prime}$ Bujur Timur. Wilayah Kota Surabaya secara umum merupakan dataran rendah dengan ketinggian 3$6 \mathrm{~m}$ di atas permukaan air laut (dataran rendah). Adapun objek penelitian SDIT Al-Uswah berada di jalan Kejawan Gebang, Keputih, Surabaya. Lokasi sekolah berada pada kawasan padat penduduk. Batasan lokasi yaitu, pada sisi Utara berbatasan dengan Permukiman penduduk, sisi Selatan dan Timur berbatasan dengan sungai, serta sisi Barat berbatasan dengan jalan Kejawan Gebang.

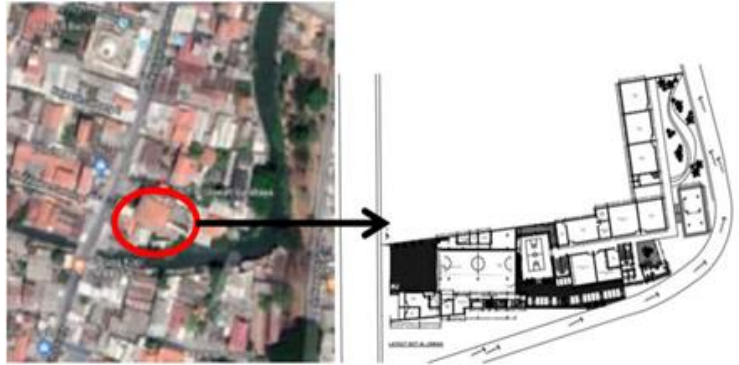

Gambar 2. Lokasi bangunan yang terletak ditengah pemukiman padat. Denah bangunan tipis berbentuk $\mathrm{L}$.

Pengamatan dan pengukuran kondisi eksisting dilakukan pada objek ruang kelas, meliputi kondisi bangunan dan pengukuran kondisi lingkungan dalam dan luar. Pengukuran kondisi lingkungan dilakukan pada dua konteks yang berbeda yaitu saat ada aktivitas belajar mengajar dan tidak ada aktivitas pembelajaran. Zona-zona yang menjadi lokasi pengukuran:

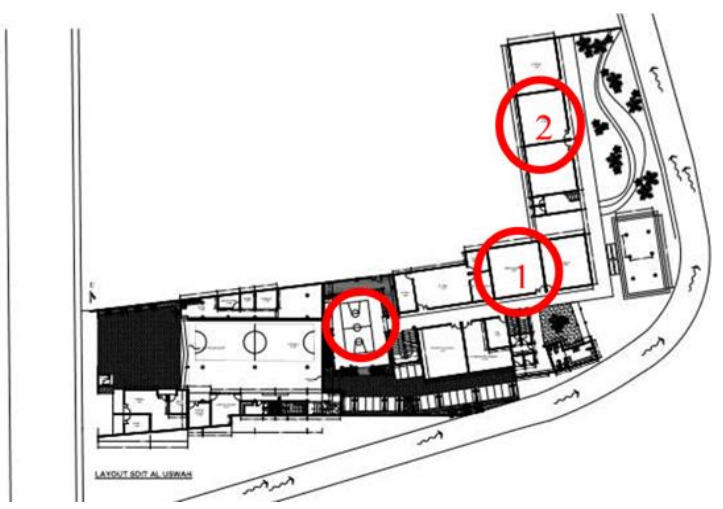

Gambar 3. Zona lokasi pengukuran.

Zona 1 dipilih pada bangunan depan tepatnya pada ruang kelas VI Abu Bakar. Ruang kelas berada di lantai 1. Ruang ini memiliki 2 sisi bukaan yang menghadap ke arah Utara dan Selatan. Ukuran jendela cukup besar dan jumlahnya cukup banyak. Sedangkan ukuran ruangan kelas sebesar $6,95 \times 6,56 \mathrm{~m}$, dengan tinggi plafon $3,9 \mathrm{~m}$ (gambar 4). Waktu pengukuran dilakukan pada 2 kondisi yaitu, pada saat ada aktivitas dan tidak ada aktivitas pembelajaran. Adapun pelaksanaan pengukuran dilakukan selama 3 hari berturut turut pada Bulan April, yaitu dua hari disaat tidak ada aktivitas pembelajaran dimana 
pengukuran dilakukan pada pagi dan sore hari. Sedang satu hari lainnya pengukuran dilakukan pada saat ada aktivitas pembelajaran dan dalam waktu pengukuran pagi, siang dan sore hari. Pada saat kondisi tidak ada aktifitas, ruang dalam keadaan kipas dan lampu yang tidak hidup. Sedangkan Pada saat kondisi ada aktifitas, ruang dalam keadaan kipas dan lampu yang dihidupkan (dalam satu ruang kelas terdapat sekitar 3-4 kipas angin).
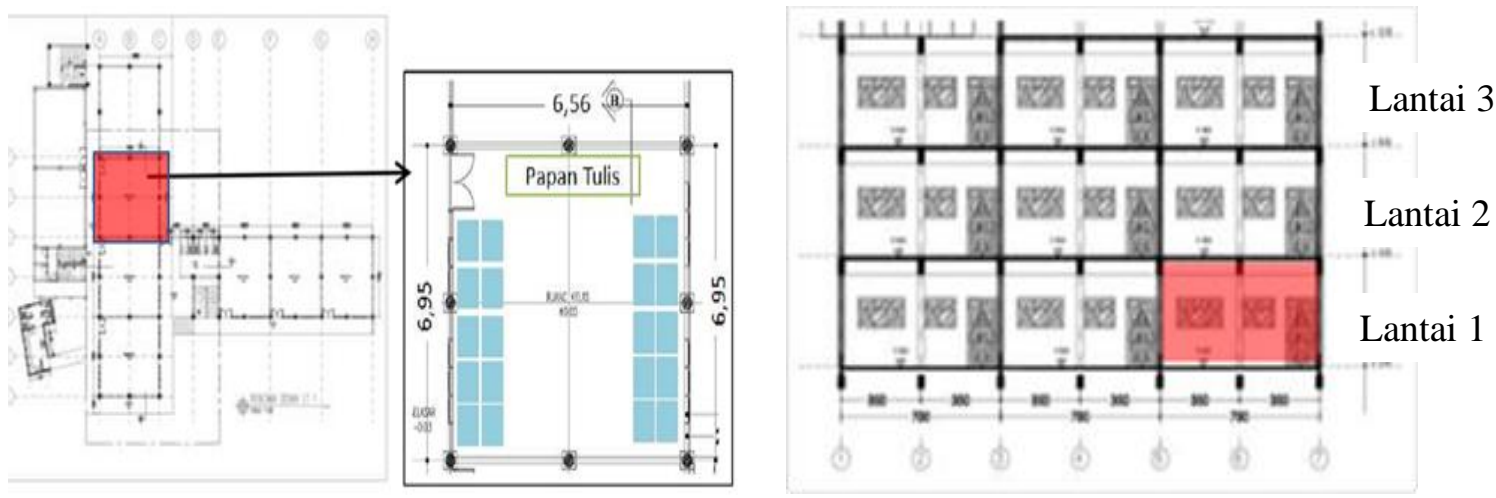

Gambar 4. Posisi dalam denah (atas) dan posisi dalam potongan (bawah) ruang kelas VI Abu Bakar sebagai wakil dari zona 1
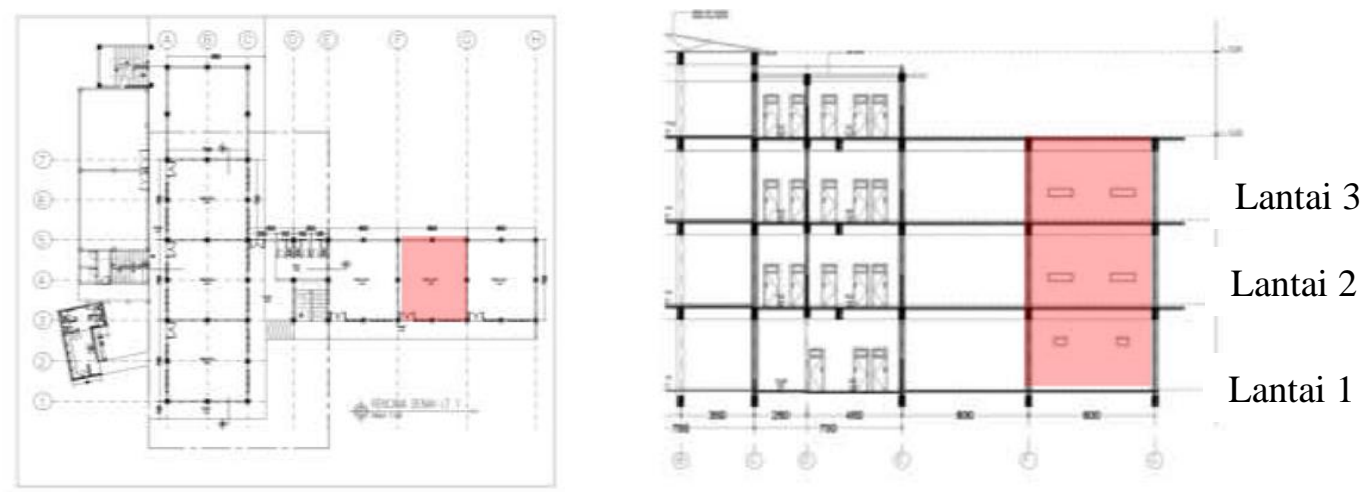

Gambar 5. Posisi dalam denah (kiri) dan posisi dalam potongan (kanan) ruang kelas I, II, III Abu Bakar sebagai wakil dari zona 2
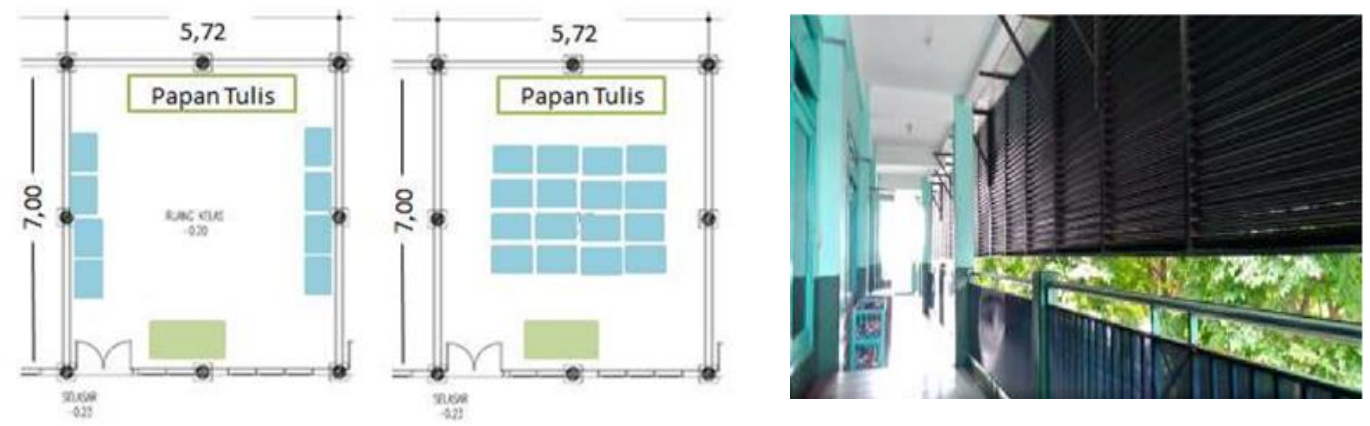

Gambar 6. Gambaran perletakan furniture pada ruang kelas zona 2 (kiri) dan selasar dengan louvre sun-screen pada lantai 2 dan 3 (kanan) 
Zona 2 merupakan bangunan belakang, yang diambil perwakilan satu kelas pada masingmasing lantai di lantai 1-3. Kelas I Abu Bakar di lantai 1, kelas II Abu Bakar di lantai 2, dan kelas III Abu Bakar di lantai 3 (gambar 5). Orientasi bangunan menghadap Timur-Barat yang cukup mendapatkan panas sinar matahari sore. Adapun ukuran ruang tipikal dari lantai 1-3 yaitu 5,72 $\mathrm{x}$ $7 \mathrm{~m}$ dengan tinggi plafon $3,28 \mathrm{~m}$. Pada zona ini terdapat selasar dibagian depan pintu masuk yang dilengkapi alat pembayang matahari berbentuk kisi-kisi (louvre shading device) dengan dimensi yang cukup besar dan berwarna gelap (gambar 6).

\section{HASIL DAN DISKUSI}

Hasil pengukuran dan pengamatan lapangan pada gedung dan ruang kelas SDIT AlUswah memberikan gambaran singkat kondisi temperature dan kelembaban, kecepatan angin serta pencahayaan dalam ruang kelas adalah sebagai berikut:

\section{a. Temperatur dan kelembaban.}

Hasil pengukuran menunjukkan bahwa rata-rata temperature di luar lebih tinggi dari temperatur dalam ruang, baik pada pagi, siang dan sore hari (gambar 7 dan gambar 8). Temperatur udara ruang cenderung di atas $30^{\circ} \mathrm{C}$, hal ini berarti temperatur udara ruang cukup tinggi, di atas temperatur nyaman $27^{\circ} \mathrm{C}$. Kelembaban udara juga rata rata cukup tinggi $(70 \%)$, di atas kelembaban udara yang nyaman (50\%) (gambar 9 dan gambar 10).

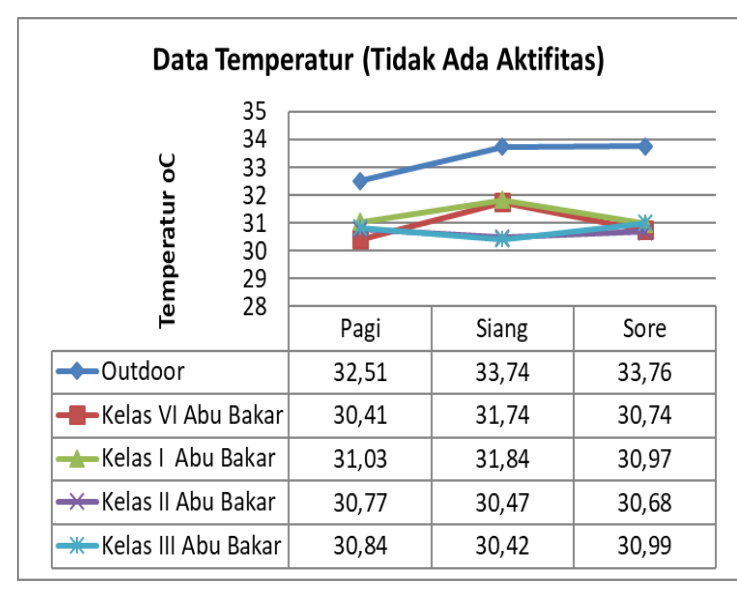

Gambar 7. Data temperatur ruang saat tidak ada aktifitas.

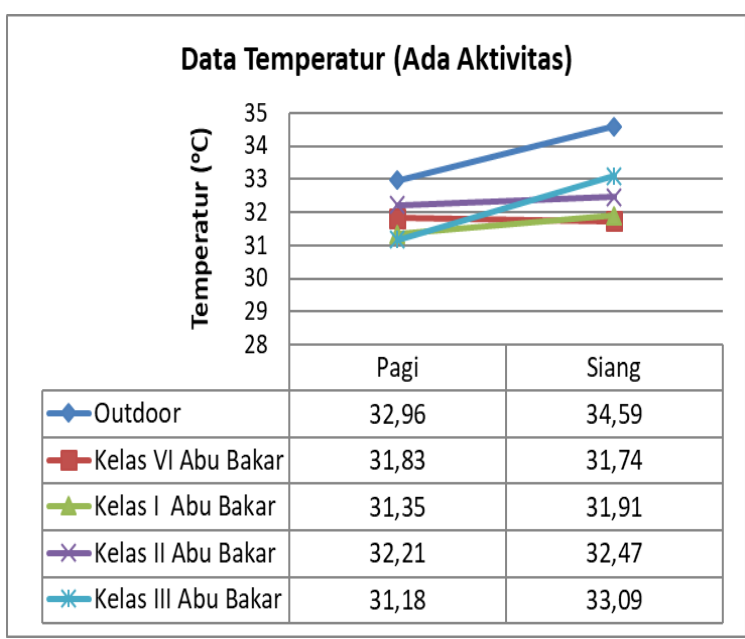

Gambar 8. Data temperatur ruang saat ada aktifitas.

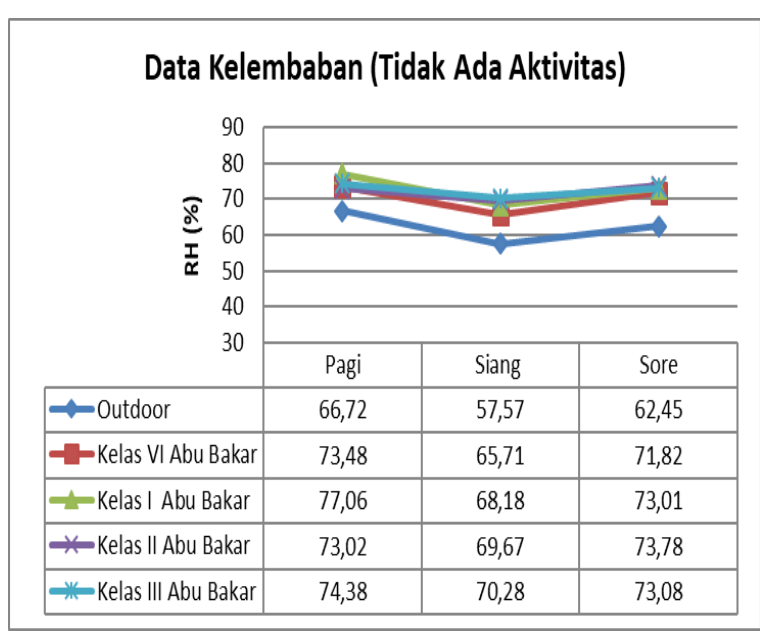

Gambar 9. Data kelembaban saat tidak ada aktifitas

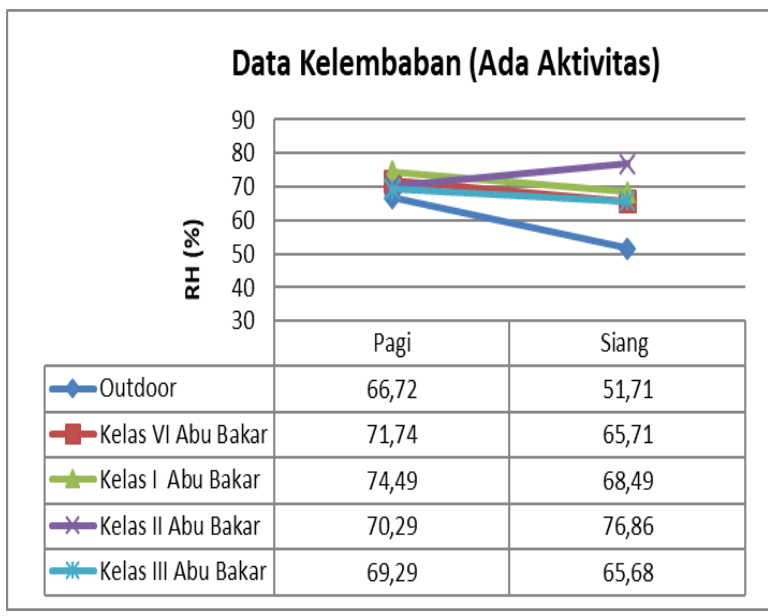

Gambar 10. Data kelembaban saat ada aktifitas. 


\section{b. Kecepatan angin.}

Kecepatan angin diharapkan dapat mnghapus panas, memberikan efek nyaman secara termal, pada suhu lingkungan setempat. Namun kecepatan angin diruang-ruang kelas di area pengukuran cenderung mendekati nilai $0,00 \mathrm{~m} / \mathrm{s}$ dan kecepatan angin tertinggi di beberapa titik mencapai $0,07 \mathrm{~m} / \mathrm{s}$ pada kondisi tanpa kegiatan (gambar 11), dan $0,29 \mathrm{~m} / \mathrm{s}$ pada saat ada kegiatan (gambar 12).

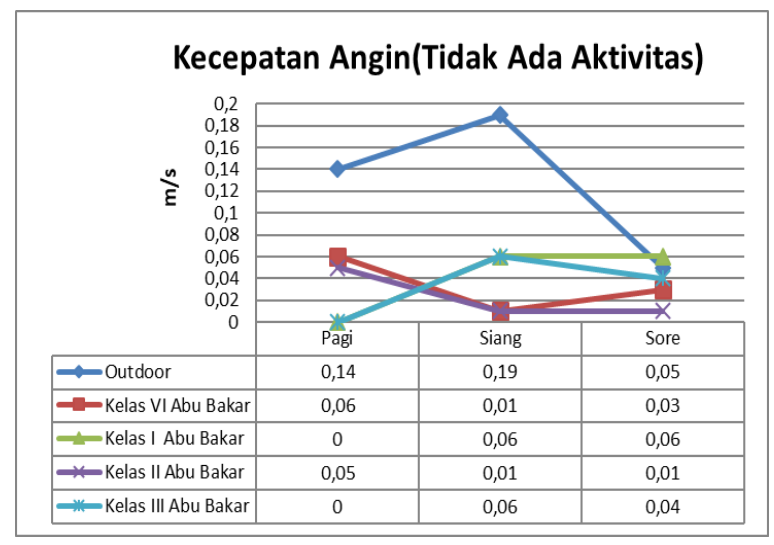

Gambar 11. Kecepatan angin dalam ruang saat tidak ada aktifitas.

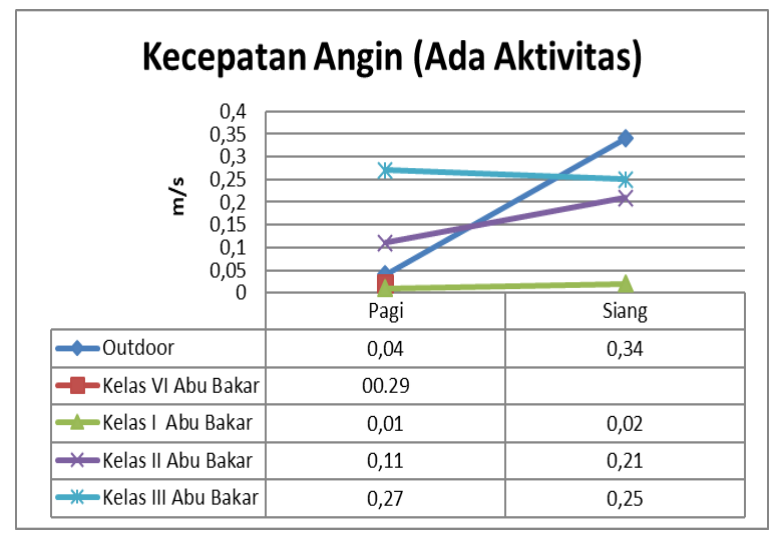

Gambar 12. Kecepatan angin dalam ruang saat ada aktifitas.

Apabila dibandingkan dengan kecepatan angin minimum yang dihitung untuk kebutuhan kenyamanan termal (tabel 2), maka kecepatan angin pada ruang kelas yang diukur baik ketika tanpa kegiatan maupun saat ada kegiatan, menunjukkan kondisi masih di bawah standar kenyamanan.
Tabel 2. .Kecepatan angin yang dibutuhkan pada temperatur dan kelembapan tertentu

\begin{tabular}{ccccc}
\hline \multicolumn{7}{c}{ PAGI } \\
\hline Posisi ruang & R.Kelas & $\begin{array}{c}\mathrm{T} \\
\left({ }^{\circ} \mathrm{C}\right)\end{array}$ & $\begin{array}{c}\text { RH } \\
(\%)\end{array}$ & $\begin{array}{c}\mathrm{V} \\
(\mathrm{m} / \mathrm{dt})\end{array}$ \\
\hline Lt.1/Zn 1 & VI & 30,41 & 73,48 & 0,59 \\
\hline Lt.1/Zn 2 & I & 31,03 & 77,06 & 0,72 \\
\hline Lt.2/Zn 2 & II & 30,77 & 73,02 & 0,64 \\
\hline Lt.2/Zn 2 & III & 30,84 & 74,38 & 0,67 \\
\hline \multicolumn{5}{c}{ SIANG } \\
\hline Lt.1/Zn 1 & VI & 31,74 & 65,71 & 0,73 \\
\hline Lt.1/Zn 2 & I & 31,84 & 68,18 & 0,76 \\
\hline Lt.2/Zn 2 & II & 30,49 & 69,67 & 0,57 \\
\hline Lt.2/Zn 2 & III & 30,42 & 70,28 & 0,57 \\
\hline Sum
\end{tabular}

Sumber: hasil perhitungan

\section{c. Pencahayaan alami.}

Dalam hal pencahayaan alami (yang diukur menggunakan nilai daylight factor/DF). Sebagian besar ruangan memiliki DF dengan nilai kurang dari satu. Pada kasus tertentu nilai DF justru sangat kecil pada sisi yang mempunyai jendela yang lebar daripada sisi yang mempunyai jendela kecil . Hal ini terjadi karena sisi tersebut memiliki selasar yang dilengkapi sun-screen bertipe louvre yang rapat dan berwarna gelap. Dilain pihak pada sisi ruang dekat dengan jendela dengan luasan kecil justru lebih terang karena jendela tersebut berada di lantai 2 dan 3 yang minim penghalang.

Dengan kondisi di atas maka diperlukan tata ulang rancangan bangunan sehingga sesuai dengan persyaratan atau standar:

a. Rancangan untuk pencahayaan alami.

Pada kelas 1 lantai 1 yang memiliki akses cahaya matahari yang kurang baik, maka diperlukan perlebaran ukuran jendela dan penerapan light shelf. Penerapan light shelf dapat membantu mendistribusikan cahaya ke dalam kelas dengan teknik pemantulan cahaya. Light shelf sebaiknya dipasang pada jendela bagian luar (eksternal), supaya dapat memperoleh cahaya matahari yang banyak dan menyalurkannya ke dalam kelas (gambar 13).

Dikarenakan pada area timur gedung sudah terdapat banyak pepohonan yang dapat menyaring panas dan silau, maka sebaiknya ukuran overhang dikecilkan supaya dapat mempermudah akses cahaya ke dalam kelas. 
Overhang dengan menggunakan material yang transparan dan memiliki opacity tinggi juga bisa digunakan karena dapat berfungsi sebagai perlindungan dari hujan, sekaligus dapat memasukkan cahaya matahari (gambar 14).

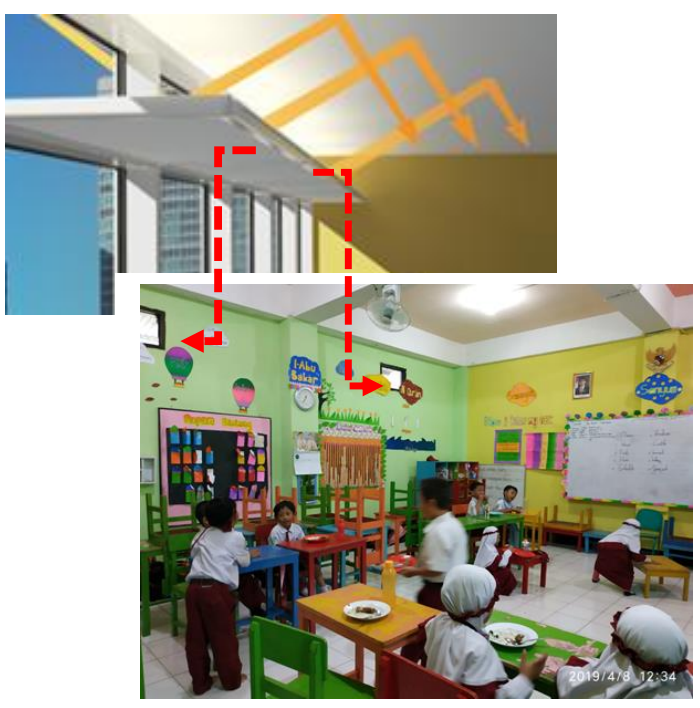

Gambar 13. Penerapan light-shelf pada jendela ruang kelas berfungsi untuk menangkap cahaya dan memasukkannya jauh kedalam.
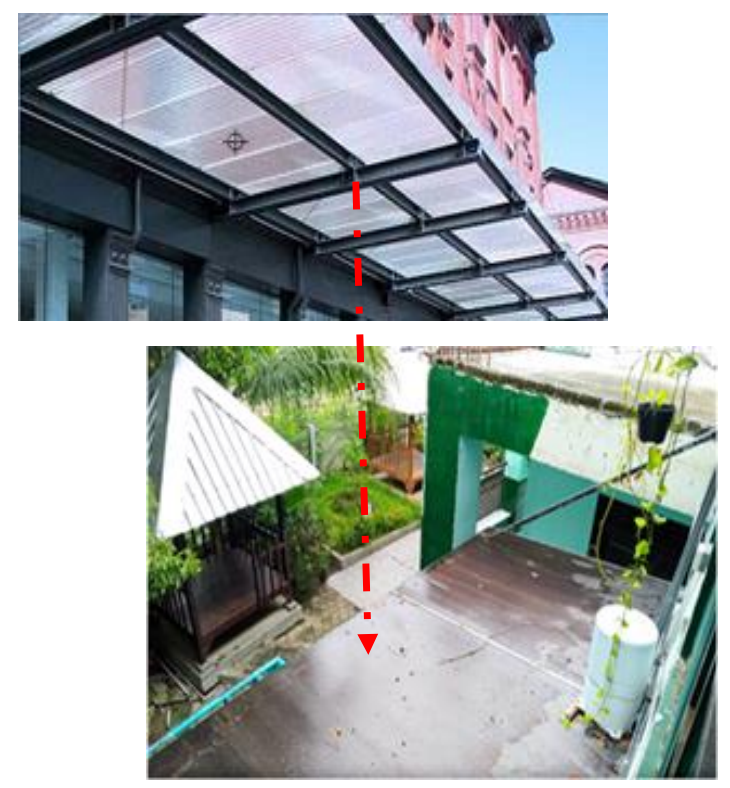

Gambar 14. Penerapan overhang transparan pada bagian timur kelas.

Pada kelas lantai 2 dan 3, terdapat kisi-kisi ventilasi yang dapat berfungsi sebagai shading device pada depan koridor kelas. Shading device ini cukup memberikan pembayangan yang baik, namun di sekitar area koridor ini memiliki tingkat penerangan cukup rendah. Solusi penerangan yang tepat adalah dengan melebarkan jarak antara kisi-kisi shading dilebarkan supaya tidak terlalu rapat, sehingga dapat memudahkan akses cahaya matahari. Penerapan louvre dapat membantu melindungi dari radiasi dan silau cahaya, namun juga dapat berfungsi memantulkan cahaya ke dalam kelas.

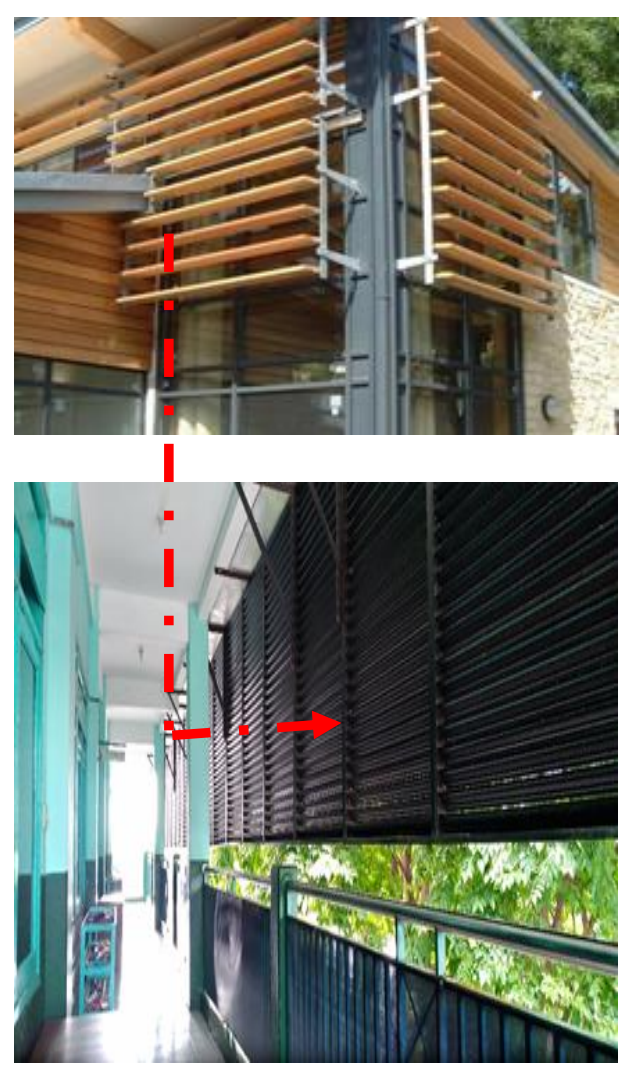

Gambar 15. Penerapan louvre pada sunshading di area koridor. Jarak antar kisi dilebarkan dengan arah horizontal untuk dapat memasukkan pencahayaan.

Untuk kelas VI lantai 1, dimensi jendela cukup besar dan terdapat pada dua sisi dinding sehingga membuat penerangan alami di kelas cukup baik. Namun, pada beberapa area yang berdekatan dengan jendela memiliki nilai penerangan yang sangat tinggi dan cenderung menghasilkan efek panas dan silau. Sehingga, diperlukan alat shading pada jendela untuk menyaring intensitas cahaya yang masuk. 
Venetian blinds dapat diterapkan pada jendela untuk membantu menyaring cahaya yang masuk supaya dalam jangkauan yang nyaman secara visualisasi. Venetian blinds juga dapat diatur dan digerakkan oleh pengguna sesuai dengan kebutuhan sehingga memiliki fleksibilitas yang tinggi (gambar 16).

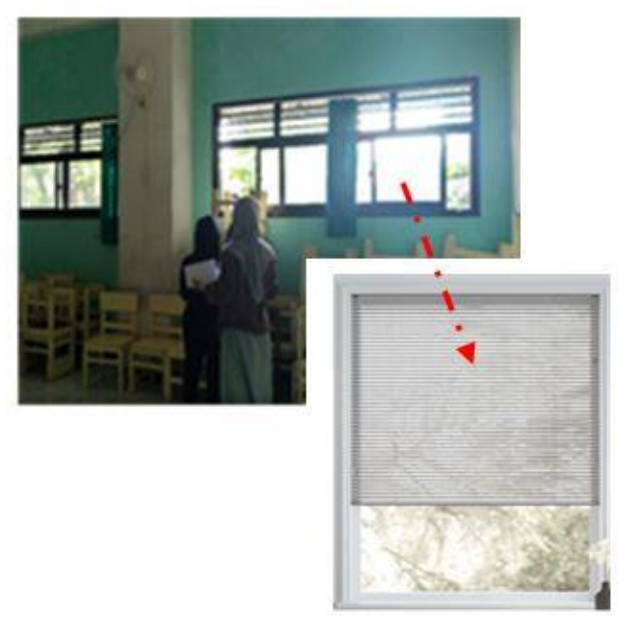

Gambar 16. Penerapan Venetian blind pada jendela ruang kelas.

b. Rancangan untuk penghawaan.

Kondisi penghawaan yang didapat dari hasil pengukuran kecepatan angin menunjukkan kurang memenuhi syarat untuk memperoleh kenyamanan. Alat bantu yang sudah diterapkan di ruang-ruang kelas di SDIT Al Uswah menunjukkan hasil yang kurang efektif untuk mengatasi permasalahan panas dan gerah di ruang kelas.

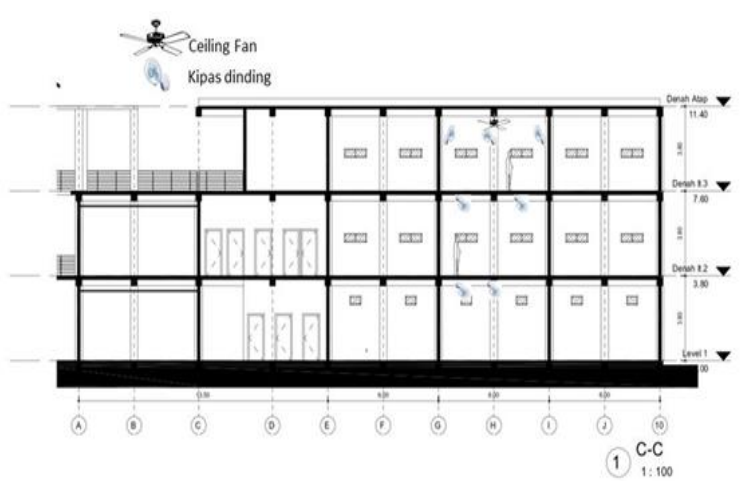

Gambar 17. Penerapan fan yang kurang efektif untuk menghalau panas.
Bila dilihat dari gambar 17, ruang-ruang dilengkapi dengan fan (kipas angin listrik), baik yang berupa ceiling fan maupun wall fan yang ditempatkan di langit-langit. Dalam kondisi tersebut sirkulasi udara tidak memungkinkan pembuangan panas ke luar ruang karena arah fan hanya ke dalam. Selain itu dengan arah fan yang menuju ke bawah, menyebabkan aliran panas dari langit-langit ikut serta turun, sehingga menambah panas ruangan. Perlu diusulkan penempatan kipas angin menyediakan kondisi nyaman bagi pengguna ruangan kegiatan belajar mengajar.

Pada umumnya, upaya-upaya secara arsitektural yang dapat dilakukan untuk memenuhi syarat penghawaan untuk ruang kelas pada sekolah dasar adalah sebagai berikut:

- Mengefektifkan ventilasi alami, yang bertujuan menghilangkan gas-gas yang tidak menyenangkan yang ditimbulkan oleh keringat dan sebagainya serta gaspembakaran $(\mathrm{CO} 2)$ yang ditimbulkan oleh pernafasan dan proses-proses metabolisme. Dalam penelitian Mishra (2015), menunjukkan hubungan positif yang signifikan antara tingkat ventilasi di ruang kelas dan kinerja akademik siswa. Untuk itu perlu diupayakan pencapaiannya.

- Sistem ventilasi mekanis harus diberikan jika ventilasi alami yang memenuhi syarat tidak memadai. Dalam hal ini, kebijakan Yayasan tidak menginginkan penerapan ventilasi mekanis/buatan dalam bentuk AC, untuk itu, hal tersebut tidak menjadi penekanan dalam usulan tindakan ini.

- Penempatan fan harus memungkinkan pelepasan udara secara maksimal dan juga memungkinkan masuknya udara segar atau sebaliknya, sehingga udara nenjadi bersih, panas tidak tertimbun yang membuat ruangan semakin tinggi temperaturnya. Dan pada gilirannya kenyamanan termal tercapai.

Guna memenuhi kebutuha tersebut dilakukan penghitungan debit ventilasi untuk menentukan jenis dan jumlah fan yang dibutuhkan. Dari tipologi ruang kelas yang ada di SD Al Uswah, dan syarat minimal pergantian udara didapatkan debit ventilasi (dalam cubic meter per menit) 57 m3/mnt. Dengan data tersebut dipilih kipas listrik tipe exhaust fan $\mathrm{dg} 18 \mathrm{Cmm}$ sebanyak 4 buah. Dengan demikian usulan yang dapat 
diberikan untuk penyelasaian masalah termal pada ruang kelas SD IT Al Uswah adalah dengan menambahkan bantuan vetilasi mekanis yang membantu memberikan aliran udara dalam ruang yang dipasang pada posisi inlet dan outlet yakni pada dinding yang berseberangan. Jenis exhaust fan yang dipasang

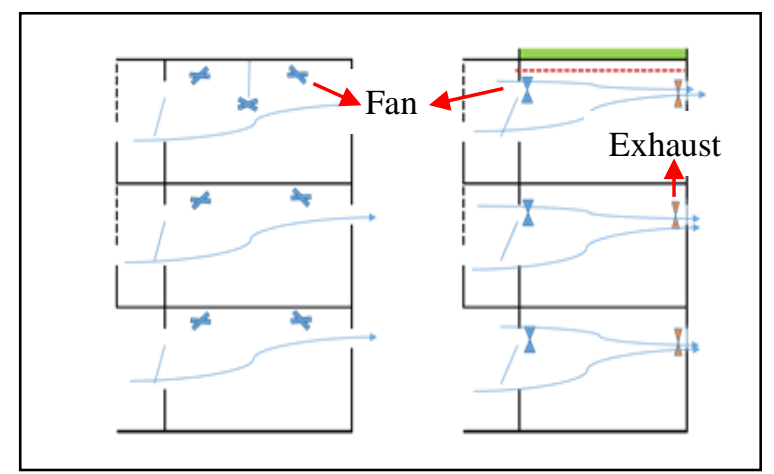

pada posisi yang tepat dengan memperhatikan posisi bukaan ruangan.

Gambar 18. Posisi eksisting dimana hanya fan yang diandalkan untuk menciptakan aliran udara (kiri). Usulan yakni dengan cara memposisikan fan listrik pada satu sisi dinding dan exhaust pada sisi dinding yang berlawanan, dengan posisi arah angin masuk (fan) dan arah keluar (exhaust) (kanan)

\section{KESIMPULAN}

Permasalahan pada rancangan penghawaan dan penerangan ruang kelas SD IT Al Uswah Surabaya menghasilkan kinerja pencahayaan dan peghawaan yang tidak memenuhi standar kenyamanan.

Usulan peningkatan kualitas pencahayaan dan penghawaan bertujuan memecahkan masalah diatas. Dengan menggunakan konsep selective environment berbasis strategi kontrol lingkungan pasif, maka penyelesaian permasalah dan saran bagi pengelola SDIT Al Uswah secara singkat adalah:

Alat pembayang matahari dirancang ulang dengan sirip-sirip yang lebih renggang, pengurangan panas atap untuk ruang lantai 3 dilakukan dengan memanfaatkan atap sebagai green roof, memberikan langit-langit ruangan, memposisikan fan listrik dengan jenis exhaust pada dinding yang berlawanan, dengan posisi arah masuk dana arah keluar.
Merancang ulang sistem solar shading yang menggunakan folding shutter, yang mana folding shutter menyediakan perangkat sebagai kontrol matahari eksternal yang sangat dinamis. Folding shutter dapat membuka atau menutup seperti daun jendela yang akan secara instan dan dramatis mengubah penampilan facade. Memungkinkan tampilan luar maksimal ketika dibuka, daun jendela menawarkan kontrol panas dan cahaya yang efektif saat menutup sepenuhnya rata ke bagian depan. Pada kasus SD Al-Uswah, folding shutter dapat ditempatkan pada bagian depan koridor lantai 2 dan 3, untuk menggantikan sun shading yang telah ada.

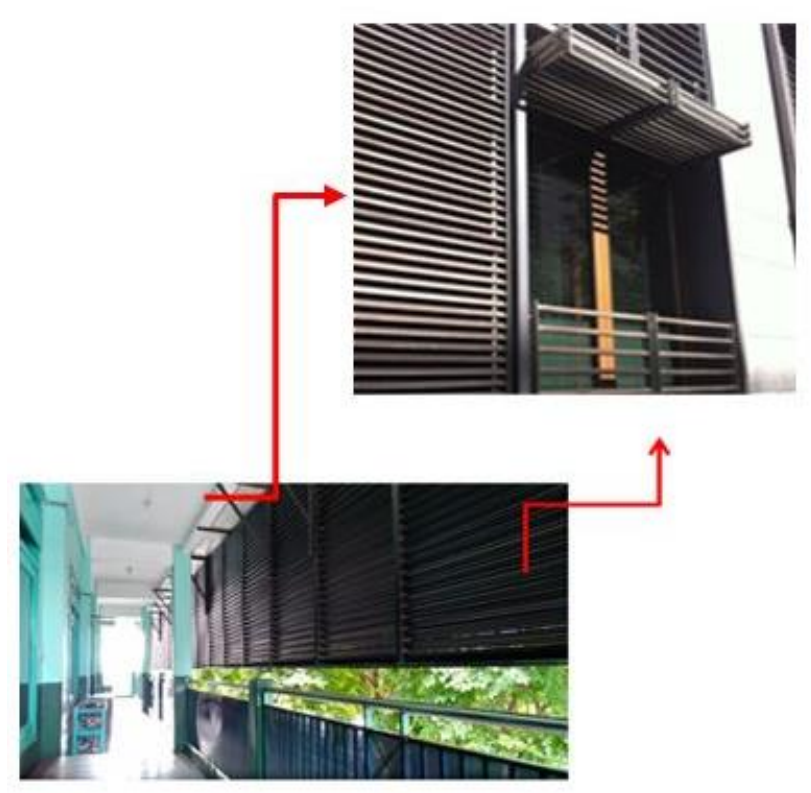

Gambar 19. Solusi penerapan folding shutter pada area koridor lantai 2 dan 3 .

Louvre eksternal banyak digunakan untuk memberikan perlindungan matahari pada bagian fasad bangunan yang menggunakan kaca. Layout louver dapat berupa horisontal dan vertikal. Tujuannya bisa untuk mengontrol masuknya cahaya, untuk menyediakan ventilasi dan perlindungan fasad dari hujan. Louvre shading dapat tersedia dalam bentuk material aluminium, kaca, tekstil, kayu, dan kisi-kisi akrilik transparan yang tersedia tergantung pada persyaratan estetika dan energetik. Pada kasus SD Al-Uswah Louvre shading dapat ditempatkan pada bagian depan koridor lantai 2 dan 3 bangunan, untuk menggantikan sun shading yang telah ada. 


\section{UCAPAN TERIMAKASIH}

Pengabdian masyarakat ini didanai dengan dana PKM Lokal ITS tahun anggaran 2019. Penulis juga mengucapkan terimakasih kepada seluruh jajaran pengelola mitra PPM yakni Yayasan Ukhuwah Islamiyah Surabaya dan pengelola SD IT Al Uswah Surabaya.

\section{REFERENSI}

Hawkes, Dean. Mc Donald, Jane dan Steemers,Koen. (2002). The Selective Environment.Spon Press. London and New YorkISBN 0-419-23530-2

Szokolay, S. V. (2004). Introduction to Architectural Science: The Basis of Sustainable Design. Oxford: Architectural Press.

Wong, N., \& Li, S. (2007). A study of the effectiveness of passive climate control in naturally ventilated residential buildings in Singapore. Building and Environment 42, 1395-1405.

Barnett, Peter. Davies, Fays. Zhang, Yufan. Barret, Lucinda. (2015) The impact of classroom design on pupils' learning final results of a holistic, multi level analysis. Journal of Building and Environment, volume 89 page 118-133, Elsevier, Ltd

Marchand, Gwen.C; Nardi, Nicholas.M; Reynolds, Douglas; Pamovkov, Stoil. (2014) The impact of the classroom built environment on students perceptions and learning. Journal of Environmental Psychology Vol 40, page 187-197. Elsevier Ltd.

De Abreu-Harbich. L.V, et al, (2018), Evaluation of strategies that improve the thermal comfort and energy saving of a classroom of an institutional building in a tropical climate, Vol (135), 257-268, Building and Environment, ScienceDirect, Elsevier, Anglo-Dutch.

Koenigsberger. OH, Ingersoll. TG, Mayhew. Alan, Szokolay. SV (1973), Manual Of Tropical Housing And Building Climatic Design, Universities Press, Orient Blackswan Private Limited, India.

Kr'uger. E.L, \& Zannin. P.H.T, (2004). Acoustic, thermal and luminous comfort in classrooms, Vol (39), 1055-1063,
Building and Environment, ScienceDirect, Elsevier, Anglo-Dutch.

Ramprasad. Vittal dan Subbaiyan. Gnanasambandam, (2017), Perceived indoor environmental quality of classrooms and outcomes: a study of a higher education institution in India, ISSN: 1745-2007, Architectural Engineering and Design Management, Taylor \& Francis.

Standar Nasional Indonesia, (2001), SNI 032396-2001 tentang Tata cara Perancangan Sistem Pencahayaan Alami Pada Bangunan Gedung, Jakarta, Badan Standarisari Nasional.

Standar Nasional Indonesia, (2001), SNI 036572-2001 tentang Tata cara Perancangan Sistem Ventilasi Dan Pengkondisian Udara Pada Bangunan Gedung, Jakarta, Badan Standarisari Nasional.

Standar Nasional Indonesia, (2001), SNI 036575-2001 tentang Tata cara Perancangan Sistem Pencahayaan Buatan Pada Bangunan Gedung, Jakarta, Badan Standarisari Nasional. 